\title{
STUDY OF SOCIETY BEHAVIOUR TO EARLY WARNING IN THE RAILWAY LEVEL CROSSING WITHOUT BARRIER IN GAYUNG KEBONSARI, SURABAYA
}

\section{STUDI PERILAKU MASYARAKAT TERHADAP EARLY WARNING PADA PERLINTASAN SEBIDANG TANPA PALANG PINTU DI GAYUNG KEBONSARI, SURABAYA}

\author{
Adita Utami ${ }^{a}$, Hera Widyastuti ${ }^{b}$ \\ a Department of Civil Engineering, Pertamina University, Jl. Teuku Nyak Arief, Simprug, Jakarta \\ Selatan, 12220 \\ ${ }^{b}$ Department of Civil Engineering, Institut Teknologi Sepuluh Nopember, Jl. Arief Rahman Hakim, \\ Sukolilo, Surabaya \\ e-mail : adita.utami@universitaspertamina.ac.id, hera.widyastuti@yahoo.co.uk
}

\begin{abstract}
Railway level crossing safety is one of the most critical issues for railways. Collisions between trains and motorized vehicles contribute most to LX accidents. Population growth and the development of economic in Indonesia affect the increase in vehicle volume, especially in the city of Surabaya. Furthermore, the increasing of vehicles volume, causing congestion at some points in Surabaya including Gayung Kebonsari railway level crossing. One of the congestion factors at the railway level crossings is the duration of closing time as the train passes through the crossing. The uncertain duration of gate closing time cause road users to be undisciplined by break through the crossing gates while the train pass through the crossings. Considering of those problems, respondents' opinion is being evaluated to see the society behaviour to early warning on reducing the number of traffic violation. A comprehensive discussion of the existing problems, lessons learned and the possible future implications that can be applied in Indonesia are presented.
\end{abstract}

Key Words: Railway Level Crossing; Accident; Society Behaviour; Regression, Binary logit

\begin{abstract}
Abstrak
Keselamatan lalu lintas pada perlintasan sebidang menjadi salah satu masalah kritis pada bidang perkeretaapian. Kecelakaan kereta dengan kendaraan bermotor memiliki kontribusi yang besar pada tingginya tingkat kecelakaan perlintasan sebidang kereta api dan jalan raya. Pertumbuhan penduduk dan perkembangan ekonomi di Indonesia mempengaruhi peningkatan volume kendaraan, terutama di kota Surabaya. Peningkatan volume kendaraan, menyebabkan kemacetan di beberapa titik di Surabaya. Salah satu faktor kemacetan di perlintasan kereta api adalah durasi waktu penutupan saat kereta melewati persimpangan. Durasi penutupan perlintasan yang tidak pasti menyebabkan pengguna jalan menjadi tidak disiplin dengan menerobos perlintasan yang berakibat pada meningkatnya tingkat kecelakaan lalu lintas yang terjadi di persimpangan sebidang tanpa palang pintu. Sehingga untuk mengatasi permasalahan tersebut, pendapat masyarakat perlu dievaluasi untuk mengetahui perilaku masyarakat terhadap early warning untuk mengurangi tingkat pelanggaran lalu lintas. Studi yang komprehensif tentang permasalahan yang terjadi,
\end{abstract}


M.I.P.I. Vol.14, No 1, April 2020 - (39-46)

pelajaran yang dapat diambil, serta kemungkinan untuk mengatasi

permasalahan dimasa yang akan datang disajikan dalam studi ini.

Kata kunci: Perlintasan Sebidang Kereta Api; Kecelakaan; Perilaku

Masyaraka; Regresi; Logit Biner

Diterima (received): 17 Maret 2020, Direvisi (revised): 08 April 2020,

Disetujui (accepted): 15 April 2020

\section{INTRODUCTION}

According to the data from Surabaya City Central Bureau of Statistics in 2017, the average population growth of Surabaya is $2.136 \%$ per year. While the economic growth of the city of Surabaya reaches $7.5 \%$ each year. Population growth and economic growth in Indonesia affect the increase in volume of vehicles in major cities in Indonesia, including Surabaya. Nowadays, the volume of vehicles in Surabaya continues to increase around 5-6\% each year ${ }^{1}$. Increasing volume of private vehicles and rapid growth of population have increasingly influenced the intensity of travel which has resulted in increased of direct access to the city centre. On the other hand, the rapid growth of population also raises the demand for access through large-capacity transportation modes through the railways ${ }^{2)}$. Trains are an efficient mass transportation for transporting large numbers of passengers, so that trains are very suitable to become urban mass transportation in crowded corridors. In addition, the train can also be used as a freight transport in large quantities as well ${ }^{3)}$. The presence of the first train in Indonesia began in 1840 during the Dutch colonial era.

One factor in congestion at the level crossing is the length of the closing time before the train passes the crossing and when the train passes the crossing. The length of time when the train passes through the crossing depends on the length of the train and other factors ${ }^{2}$. Nowadays, the number of railway level crossings on Java and Sumatra reaches 5,211 ; with 1,174 are guarded and 3,419 level crossings are not maintained. With an official crossing of 4,593; and unofficial 618 and it is estimated that the unofficial railway level crossing will continue to increase along with the increasing of vehicle volume. The increase in vehicle volume also causes congestion at several points in Surabaya. One of the points of congestion in Surabaya is congestion caused by the crossing of railway lines and highways ${ }^{2)}$. This is in accordance with Law No. 23 of 2007 article 124 which states that: "in the intersection of a plot between the railway and road, road users must prioritize train travel", so that if the crossing of the two modes is still in the same level, the road must be closed when the train crosses an intersection. But in reality, there are still many drivers who are not orderly and there is still a lack of safety equipment and a system that regulates at level crossings which results in a high number of traffic accidents at level crossings ${ }^{4)}$.

Accidents at railway level crossings often give rise to serious material and human damage and hamper railway safety reputation, although the majority of accidents are caused by vehicle driver violations. LX safety is one of the most critical issues for railways which needs to be tackled urgently ${ }^{5-6)}$. Research on safety at level crossings continues to be developed specifically to develop a qualitative approach, to understand the potential reasons for accidents at level crossings, some method are being conducted such as through surveys, respondent's interviews by using questionnaires ${ }^{7}$, Focus Group Discussion methods ${ }^{8}$, the use of driving simulators ${ }^{9}$, and even directly collecting field data.

\section{CASE STUDY LOCATIONS}

The research about society behaviour to early warning in railway level crossings without barrier which has been conducted at Surabaya Indonesia was intended to reduce the number of motorcycle accident in railway level crossings. Through this research, it is expected to be able to identify the factors that influence public compliance with the early warning system at the level crossings without barrier in Gayung Kebonsari, Surabaya.

Based on Surabaya's census survey in 2010 , the population in Surabaya was $2,874,700$ and this was distributed across 31 -sub districts. Surabaya is located at $7^{\circ} 14^{\prime}$ South latitude and $112^{\circ} 44^{\prime}$ 'East longitude and has an area 326.37 $\mathrm{km}^{2}$. As the second largest city in Indonesia and the capital of the East Java province of Indonesia ${ }^{1)}$, it is no wonder that the amount of motorcycle in Surabaya at 2008 reach 4,544,538 while at the same year the number of cars in Surabaya are $1,197,018$ vehicles $^{10}$. In the other hands, the increasing of the intensity of the trip led to an increase in demand for access via the railroad. 
To give a rough data on the number of accidents happened in railway level crossing in Surabaya, Table 1 shows the number of accidents during $2011-2017$.

Table 1.

Number of accidents during $2011-2017$

\begin{tabular}{ccccc}
\hline Year & \multicolumn{4}{c}{ Accident in Railway Level Crossing } \\
& $\begin{array}{c}\text { Total } \\
\text { Accident }\end{array}$ & Fatalities & $\begin{array}{c}\text { Heavy } \\
\text { injury }\end{array}$ & $\begin{array}{c}\text { Light } \\
\text { injury }\end{array}$ \\
\hline 2011 & 45 & 3 & 3 & 0 \\
2012 & 34 & 21 & 18 & 3 \\
2013 & 32 & 27 & 18 & 3 \\
2014 & 44 & 33 & 24 & 9 \\
2015 & 40 & 40 & 3 & 21 \\
2016 & 35 & 39 & 7 & 3 \\
2017 & 54 & 46 & 15 & 9 \\
Total & 284 & 209 & 88 & 48 \\
\hline
\end{tabular}

Sources: DAOP 7, DAOP 8, and DAOP 9, 2017

From Table 1, it can be concluded that there was a fluctuation on the number of accidents in railway level crossing in the past 7 years from 2011 - 2017, although there has been a reducing in number during the year of 2012 2013, from 2016 - 2017 there has been a significant increase. This is caused by the increasing number of vehicles without accompanied by new rules or regulation from the related institution.

\section{LITERATURE REVIEW}

\section{Previous Research}

Based on the previous research, different types of warning devices railway used at crossings significantly influence drivers' behaviour. For instance, violations of warning devices have been detected in previous research. Pickett and Grayson (1996) have conducted a research related to driver's behaviour by doing interviewed to 100 drivers after being seen to cross railway level crossings when the red stoplights were flashing. Results from the interviews concluded that the majority of respondents showed an understanding of the operation of the crossings but an understanding of level crossing signals was on the whole poor compared with that of conventional road traffic signals ${ }^{11)}$.

In 2011, Li-Sian Tey, et al. conducted a study to measure the driver's response to a level crossing that was equipped with a stop sign (passive), APILL, and a protective doorstop equipped with APILL. In this study, the driver's response was generated from a field survey and observed the driver's response to using a driving simulator in the laboratory. The two simulation forms are then compared to the results of the driver's response. Responses observed include compliance to stop the vehicle during early warning, work, reduce vehicle speed and pause before crossing the crossing, and the vehicle's braking position is analysed from the speed profile. The results of the Li-Sian Tey, et al. study show that the average driver's response to level crossings with passive/no-door signs tends to be poor/non-compliant when compared to level crossings that use an active early warning and barrier doors. This clearly shows that drivers behave differently towards different warning systems, especially in passive systems, which are usually used in rural areas ${ }^{12)}$.

In 2009, Hera Widyastuti, et al. conducted a study related to the evaluation of the Responsible Riding Program which was a program to reduce the number of accidents for motorcyclists. The Responsible Riding Program campaign program aims to provide understanding to citizens about the importance of safety by mutual respect for each other and to be responsible not only for themselves but also for others. The program also aims to reduce motorcycle accidents caused by negligence on the road to ensure traffic safety, discipline and maintain a good flow of traffic in Surabaya. In this study, data was collected from interviews with motorcycle riders. The sampling method used is a probability sampling method which according to Cochran (1991) means a simple random sampling method is being used. 183 respondents were successfully interviewed to find out their opinions about the effectiveness of Responsible Riding Program for reducing motorcycle accidents ${ }^{13)}$.

\section{Literature of Stated Preference}

According to economist Paul Samuelson (1938), revealed preference survey technique is a form of survey technique based on reality and circumstances in the field ${ }^{14}$ ). This survey technique is a form of questionnaire survey that asks respondents about something that is already evident in the object of research. So that respondents were asked to give a response to each answer to each question, from various choices of answers that have been provided. Revealed preference technique has a weakness, among others, in terms of estimating the individual response to a state of service that at present does not yet exist and can be a situation that is far different from the current situation. 
In contrast to revealed preference techniques, stated preference techniques asked respondents about a matter that was not yet real in the field, so it was still minded. So that respondents in giving answers are still in the shadow because they have never experienced the conditions that exist now. Stated preference technique is a data collection technique that refers to the approach to the opinions of respondents in dealing with various alternative choices. This technique uses experimental design to make a number of alternative imaginary situations. Stated preference experimental designs must be structured in such a way that the combination of all the factors included in the study has a correlation with various alternatives ${ }^{15)}$.

\section{METHODS}

\section{Designed of Stated Preference Technique}

Stated Preference technique is an approach to respondents to know their response to different situations. In this technique, the researcher can fully control the factors that exist in the hypothesized situation. Each respondent was asked about the response if they were faced with the situation given in the actual conditions (how are their preference to the options offered).

In this research, the respondent was interviewed to identify the characteristics, and the obedience to early warning system in railway level crossing. Through this research, it is expected to identify the factors that influence public compliance with the early warning system at the level crossings without barrier in Gayung Kebonsari, Surabaya.

\section{Data Sampling}

The respondent in this study were society who often pass through the railway level crossing without barrier in Gayung Kebonsari, Surabaya. The selection of respondents in this study refers to the stratified random sampling method where the sampling process is through the process of dividing the population into strata (strategic location around railway level crossing, such as: office area, school, and restaurant), selecting simple random samples from each stratum and combining them into a sample to estimate the population parameters. To determine the number of samples to be used in the analysis of society expectations using the Slovin formula as follows ${ }^{16)}$.

$$
n=\frac{N}{1+N e^{2}}
$$

$n$ : Samples of Road Users around the railway level Crossing

$N$ : Number of populations living in the District

$e$ : Percent of allowance for inaccuracy due to tolerable sampling errors / $95 \%$ precision value or sig. $=0.05$.

$$
n=\frac{18,074}{1+18,074 \times 0.05^{2}}=400 \text { samples }
$$

for e $90 \%$ or sig. $=0.1$

$$
n=\frac{18,074}{1+18,074 \times 0.1^{2}}=100 \text { samples }
$$

So, based on the results of these calculations the minimum number of samples that need to be taken in the field is 100 samples. In this study, 101 samples were taken with the aim that the data obtained became more valid.

\section{Determining Research Variable}

In this research society behaviour is defined as the willingness of the society to choose to be obedient (obey) or disobey the early warning system in railway level crossing by topping at the stop line when early warning has been sounded until the train has crossed the railway level crossing without barrier and the early warning stops. Society behaviour is defined as dependent variable. Binary data is dependent variable with two responses, for example obey the early warning system is 0 , disobey the early warning system is 1 and vice versa. For independent variable, there are 7 variables which has been used in this research. Those 7 variables consist of: Gender, Age, Job, Educational level, Income, crossings frequency in a day, and waiting time before trains crossing the railway level crossings

\section{Model Equation}

The data obtained from questionnaire surveys and interviews were then analysed by using descriptive statistical analysis, which were drawn in the form of pie charts. The pie chart explains the socio-economic characteristics of the respondent around Gayung Kebonsari Railway level crossing. From the pie chart diagram, the percentage of respondent who obey the early warning system and respondent who disobey the early warning system could be determined. The next analysis is binary logistic regression analysis ${ }^{17}$ ). Binary logit regression analysis (binary logistic regression) is used to determine the probability percentage of respondents who obey the early warning system 
and respondent who disobey the early warning system in Gayung Kebonsari railway level crossing. In addition, binary logistic regression analysis can also be used to determine the dominant variables/attributes that influence respondent's behaviour to Early Warning System in railway level crossing. To determine the approximate value of probability, obey/disobey the early warning system can be calculated using the following formula ${ }^{17)}$ :

$$
\ln \frac{p}{1-p}=\beta_{0}+\beta_{1} X_{1}+\beta_{2} X_{2}+\cdots+\beta_{k} X_{k}
$$

$\beta_{0}+\beta_{1}+\beta_{2}+\beta_{k} \quad=$ Binary data with two responses, for example obey the early warning system (0), disobey the early warning system (1). Binary data is dependent variable;

$X \quad=$ an independent variable, which has an influence factor in the society behaviour to early warning system.

After this calculation is completed, the exponential value of exp will be used to calculate the approximate value of the probability using the following formula ${ }^{15)}$ :

$$
\begin{aligned}
& \left.P_{\text {(obey }}\right)=\frac{1}{1+\exp ^{\operatorname{logit}(p)}} \\
& \left.P_{\text {(disobey) }}\right)=\frac{1}{1+\exp ^{\operatorname{logit}(p)}}
\end{aligned}
$$

To determine the factors that influence the independent variable with the dependent variable, it can be determined by comparing the significant value, i.e. if the value is sig. $<\alpha$, with a tolerance value of $\alpha=0.05 \%$, then the variable has an effect, but if the value is sig.> $\alpha$ then the variable has no effect.

\section{RESULTS AND DISCUSSION}

This research was conducted to investigate how the respondent characteristics around railway level crossings as well as how the potential and model of the public compliance to early warning system. The primary data were collected by direct interview by using questionnaires. The survey in this study used a stated preference technique.

From the distribution of respondent's behaviour obey/disobey the early warning system (breaking through when early warning sirens were sounded), from Figure 1 it was known that $34.5 \%$ of respondents had broken through when early warning sirens had been sounded and $65.5 \%$ of respondents never broke through when early warning sirens were sounded. Distribution of obey/disobey the early warning system (breaking through when early warning sirens have been sounded). While for the general survey result are presented on Table 2.

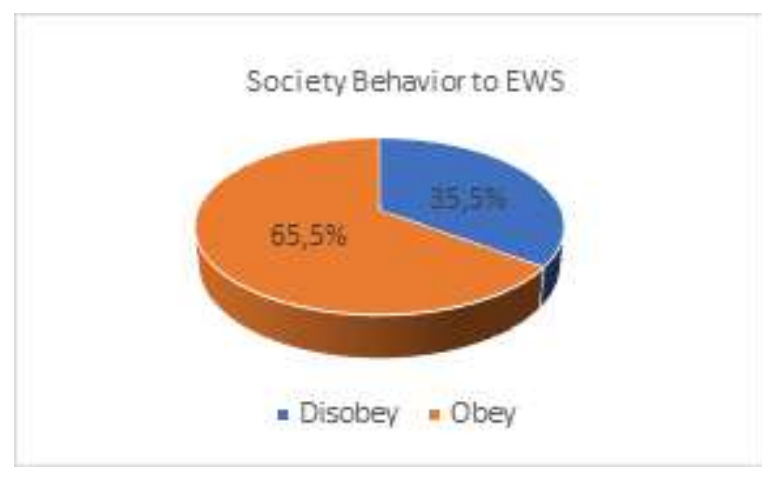

Figure 1.

Distribution of Respondents Behaviour

\section{Probability of Public Compliance to Early Warning System}

Based on the results of the Wald test with binary logistic regression for independent variables on the dependent variable, it can be seen that the independent variables significantly influence the dependent variable because the Wald sig test $\mathrm{p}$-value value $<\alpha$. Where is the value of $\alpha=0.05$. Assumptions that can be taken in testing by looking at the $p$-value:

- Rejected HO if significant $\leq \alpha$, it can be concluded that the independent variable has a significant effect on the dependent variable.

- Accept HO if significant> $\alpha$, it can be concluded that the independent variable has no significant effect on the dependent variable. The independent Variables that Influence the public compliance to early warning system are presented in Table 3.

Table 3 shows that the respondent's crossing frequency in a day and waiting time before trains passing through railway level crossing variable has a significant effect on the dependent variable of public compliances (obey/disobey the EWS) because the Wald sig test shown that $p$-value $<\alpha$ which are 0,017 and 0,018 both $<0.005$ so that the decision is $\mathrm{HO}$ rejected, where the value of $\alpha=0.05$. To analyse how much the probability of those dependent variable influences the public compliances to Early Warning system is carried out by binary logistic regression method, where the variables are dichotomous with two possibilities, those are 0 : obey the EWS and 1: disobey the EWS. 
General Survey Result Data

\begin{tabular}{|c|c|c|c|}
\hline Variable & \multicolumn{3}{|c|}{ Percentage } \\
\hline Gender & Male: $61 \%$ & Female: $39 \%$ & \\
\hline Age & $\begin{array}{l}<18: 6 \% \\
46-55: 6 \%\end{array}$ & $\begin{array}{l}\text { 19-30: } 69 \% \\
>55: 1 \%\end{array}$ & $31-45: 18 \%$ \\
\hline Educational Level & $\begin{array}{l}\text { Junior High School: 5\% } \\
\text { Senior High school: 39\% } \\
\text { Bachelor: } 53 \% \\
\text { Postgraduate: } 3 \%\end{array}$ & & \\
\hline Job & $\begin{array}{l}\text { Government employee: } 9 \% \\
\text { Student: } 35 \%\end{array}$ & $\begin{array}{l}\text { Employee: } 36 \% \\
\text { Other: } 10 \%\end{array}$ & Entrepreneur: $10 \%$ \\
\hline Income & $\begin{array}{l}\text { Rp. } 500 k-<\text { Rp. } 1.500 .000: 14 \% \\
\text { Rp. } 2.500 k-\text { Rp. } 5.000 .000: 36 \% \\
\text { Have no salary: } 22 \%\end{array}$ & & $\begin{array}{l}\text { Rp. } 1500 k-<\text { Rp. } 2.500 .000: 10 \% \\
>\text { Rp. } 5000.000: 18 \%\end{array}$ \\
\hline Crossing Frequency & $\begin{array}{l}1 \text { time: } 12.9 \% \\
>2 \text { times: } 12.9 \%\end{array}$ & & $\begin{array}{l}2 \text { times: } 34.7 \% \\
\text { Random: } 39.6 \%\end{array}$ \\
\hline Waiting Time & $15 s: 14.9 \%$ & 20s: $10.9 \%$ & \\
\hline Before Train & $25 \mathrm{~s}: 16.8 \%$ & 30 s: $24.8 \%$ & \\
\hline Passing Through & $35 \mathrm{~s}: 28.7 \%$ & & \\
\hline
\end{tabular}

Table 3.

Dependent variables that influence the public compliance to EWS

\begin{tabular}{lccc}
\hline Dependent Variable & P-value & $\alpha=5 \%$ & Decision \\
\hline Respondent's Crossing Frequency in a day & 0.018 & 0.05 & Ho Rejected \\
Waiting Time Before Train Passing Through & 0.017 & 0.05 & Ho Rejected \\
\hline
\end{tabular}

Logic Model Equation of Crossing Frequency Variable

$$
\begin{aligned}
\operatorname{logit}(P) & =\frac{p}{1-p}=\beta_{0}+\beta_{1}(X) \\
& =-1.357+0.334 \text { Crossing }
\end{aligned}
$$

Frequency (2)

$$
=-0.325
$$

Probability

$$
\begin{aligned}
& P=\frac{\exp ^{\operatorname{logit}(p)}}{1+\exp ^{\operatorname{logit}(p)}}=\frac{\exp ^{-0.325}}{1+e x p^{-0.325}} \\
& P=\frac{2.718^{-0.325}}{1+2.718^{-0.325}}=0.419 \approx 42 \%
\end{aligned}
$$

Thus, it can be concluded that the respondents who passed the crossing with an uncertain frequency in a day had the potential to commit violations with a probability value reaching $42 \%$.

\section{Logic Model Equation of Waiting Time Before Train Passing Through the Railway Level Crossing}

$$
\begin{aligned}
\operatorname{logit}(P) & =\frac{p}{1-p}=\beta_{0}+\beta_{1}(X) \\
& =1.599-1.337 \text { waiting time (1) } \\
& =0.262
\end{aligned}
$$

Probability

$$
\begin{aligned}
& P=\frac{\exp ^{\operatorname{logit}(p)}}{1+\exp p^{\log i t(p)}}=\frac{\exp ^{0.262}}{1+e x p^{0.262}} \\
& P=\frac{2.718^{0.262}}{1+2.718^{0.262}}=0.56 .5 \approx 56.5 \%
\end{aligned}
$$

\section{CONCLUSION}

This paper examines that accidents at railway level crossings often give rise to serious material and human damage and hamper railway safety reputation. The number of accidents in railway level crossing especially in Surabaya in the past 7 years from 2011-2017, there has been a reducing in number during the year of 2012-2013, from 2016-2017 there has been a significant increase and the total accident in the railway level crossing in the last 6 years is 284 accidents. From the previous research are stated that the majority of accidents are caused by driver violations.

Some factors that affected society behaviour to obey/disobey the early warning system are determined. From the Wald test with binary logistic regression analysis, there are two factors that affect the society behaviour to disobey the early warning system (by breaking through when early warning sirens were sounded) and have no willing to 
wait until the train passing through the railway level crossing and early warning sirens were stopped.

From the analysis it can be conclude that uncertain frequency in a day had the potential to commit violations with a probability value reaching $42 \%$. While, the waiting time before the train passed is too long and had the potential to commit a violation with a probability value reaching $56.5 \%$.

\section{REFERENCES}

1. Surabaya Central Bureau of Statistics, Statistik Pertumbuhan Volume Kendaraan Surabaya, Surabaya: BPS, 2017.

2. Utami, A., and Widyastuti, H., Model Panjang Antrian Kendaraan pada Perlintasan Sebidang Tanpa Palang Pintu (Studi Kasus: Perlintasan Sebidang Jl. Gayung Kebonsari Surabaya), Jurnal Aplikasi Teknik Sipil, Vol. 17, No. 23, 2019, pp27-34.

3. Widyastuti, H., Herijanto, W., Agung, A., Kartika, G., and Rahardjo, B., Railway infrastructure to support inter-modal transportation from port to hinterland (case Study-Manyar port), Procedia Soc. Behav. Sci., Vol. 227, 2015, pp 181-185.

4. Widyastuti, H., Utami, A., and Putra, M.I., Model of Queuing in the Railway Level Crossings (Case Study: Railway Level Crossings in Jemursari Surabaya), Atlantis Press - Advance in Engineering Research, Vol. 186, 2018, pp225-232.

5. Mekki, A., Ghazel, M., Toguyeni, A., Validation of a new functional design of automatic protection systems at level crossings with model-checking techniques, IEEE Trans. Intell. Transport. Syst., Vol. 13 (2), 2012, pp 714-723.

6. Liu, B., Ghazel, M., Toguyeni, A., Modelbased diagnosis of multi-track level crossing plants, IEEE Trans. Intell. Transport. Syst., Vol. 17 (2), 2016, pp 546-556.

7. Read, G.J., Salmon, P.M., Lenné, M.G., Stanton, N.A., Walking the line: understanding pedestrian behaviour and risk at rail level crossings with cognitive work analysis, Appl. Ergon., Vol. 53, 2016, pp209-227.
8. Stefanova, T., Burkhardt, J.-M., Filtness, A., Wullems, C., Rakotonirainy, A., Delhomme, P., Systems-based approach to investigate unsafe pedestrian behaviour at level crossings, Acc. Anal. Prevent., Vol. 81 (0), 2015, pp 167-186.

9. Larue, G.S., Rakotonirainy, A., Haworth, N.L., Darvell, M., Assessing driver acceptance of Intelligent Transport Systems in the context of railway level crossings, Transport. Res. Part F: Traff. Psychol. Behav., Vol. 30, 2015, pp1-13.

10. Surabaya Police Department, Laporan Pelaksanaan Kampanye Keselamatan untuk Semua Pengguna Jalan Responsible Riding, Periode 3 September-31 Oktober 2010.

11. Pickett, M.W., Grayson, G.B, Vehicle driver behaviour at level crossings, Health and safety Executive, Sheffield., 1996, p52.

12. L. Tey, L. Ferreira, and Wallace, A., Measuring driver responses at railway level crossings, Accid. Anal. Prev., Vol. 43, No. 6, 2011, pp2134-2141.

13. Widyastuti, H., Kartika, G., Fathir M., Widyanie A., Evaluation of Responsible Riding Program on Reducing Number of Motorcycle Accident, Publisher: Eastern Asia Society for Transportation Studies. Vol.7, 2019.

14. Samuelson, P.A., A note on the pure theory of consumers' behaviour, Economica, New Series, Vol. 5 (17), 1938, pp61-71.

15. Soimun, A., and Widyastuti H., Analisis Probabilitas Perpindahan Moda Pengguna Kendaraan Pribadi (Sepeda Motor Dan Mobil) Ke Kereta Api Commuter Surabaya Sidoarjo, Master Thesis: Institut Teknologi Sepuluh Nopember, Surabaya, 2018.

16. Sevilla, C.G., et. Al., Research Methods (Revised Edition), Rex Printing Company, Quezon City, 2007.

17. Nurdiansyah, M.F., and Widyastuti, H., Analisis Probabilitas Perpindahan Moda dari Bus ke Kereta Api Siliwangi Jurusan Sukabumi-Cianjur Menggunakan Analisis Regresi Logit Biner, J. Tek. ITS, Vol. 4, No. 1, 2015. 
M.I.P.I. Vol.14, No 1, April 2020 - (39-46)

(halaman ini sengaja dikosongkan) 